\title{
Microbiological evaluation of the efficacy of two new biodetergents on multidrug-resistant nosocomial pathogens Giorgio Liguori1 ${ }^{1}$ Maria Bagattini², Francesca Gallè ${ }^{1}$, Valeria Quartucci² Valeria Di Onofrio ${ }^{1}$, Mario Negrone ${ }^{3}$ and Maria Triassi ${ }^{2}$
}

\author{
Address: ${ }^{1}$ Cattedra di Igiene ed Epidemiologia, Università degli studi di Napoli "Parthenope", Napoli, Italy, ${ }^{2}$ Dipartimento di Scienze Mediche \\ Preventive, Sezione di Igiene, Università degli studi di Napoli "FedericoII", Napoli, Italy and 'Servizio di Igiene degli alimenti e della nutrizione, \\ Dipartimento di Medicina Preventiva, Agenzia di Sanità Pubblica, Potenza, Italy \\ Email: Giorgio Liguori - giorgio.liguori@uniparthenope.it; Maria Bagattini* - maria.bagattini@unina.it; \\ Francesca Gallè - francesca.galle@uniparthenope.it; Valeria Quartucci - vquartucci@yahoo.it; Valeria Di Onofrio - valeriadionofrio@libero.it; \\ Mario Negrone - marionegrone@yahoo.it; Maria Triassi - triassi@unina.it \\ * Corresponding author
}

Published: 16 December 2009

Annals of Clinical Microbiology and Antimicrobials 2009, 8:35 doi:10.1 I86/1476-07II-8-35

This article is available from: http://www.ann-clinmicrob.com/content/8/I/35

(C) 2009 Liguori et al; licensee BioMed Central Ltd.

This is an Open Access article distributed under the terms of the Creative Commons Attribution License (http://creativecommons.org/licenses/by/2.0), which permits unrestricted use, distribution, and reproduction in any medium, provided the original work is properly cited.
Received: 28 September 2009

Accepted: 16 December 2009

\begin{abstract}
Background: In the last few years, several outbreaks of nosocomial infections caused by multidrug-resistant pathogenic agents have been observed, and various biocides products were developed in order to control this phenomenon. We investigated the efficacy of two natural biodetergents composed of plants and kelps extracts, BATTI and BATT2, against multidrugresistant strains.
\end{abstract}

Methods: In-vitro antibacterial efficacy of BATTI and BATT2 against nosocomial multidrugresistant isolates was assessed using a suspension-inhibition test, with and without bovine serum albumin (BSA). The test was also carried out on glass surfaces with and without BSA.

Results: In vitro tests with both biocidal disinfectants at $25 \%$ concentration demonstrated an overall drop in bacterial, mould and yeast counts after 10 min of contact with or without organic substances. For Pseudomonas aeruginosa, it was necessary to use undiluted disinfectants with and without an organic substance. The same results were obtained in tests carried out on glass surfaces for all strains.

Conclusions: The natural products BATTI and BATT2 behave like good biocides even in presence of organic substances. The use of both disinfectants may be beneficial for reducing hospital-acquired pathogens that are not susceptible to disinfectants.

However, it has to be stressed that all these experiments were carried out in vitro and they still require validation from use in clinical practice.

\section{Introduction}

At present, biocides are an integral component of clinical medicine, and serve to prevent the dissemination of nosocomial pathogens in the hospital environment [1]. In the last few years, despite remarkable progress in our knowledge of risk factors, prevention and control measures, the incidence of nosocomial infections has not decreased, and many outbreaks have been caused by new multidrug- 
resistant pathogens that have been selected by excessive and often irrational use of antibiotics [2,3]. These microorganisms are resistant to the majority of antibiotics and to many disinfectants, which has resulted in an increase in environmental contamination [4,5]. In many cases, it has been demonstrated that the molecular mechanisms responsible for antibiotic resistance are the same as those implicated in lack of susceptibility to biocides; anyway, some biocides have the ability to select for antibiotic resistant strains and vice versa [6-10]. Also, organic contamination reduces the effectiveness of disinfectants and antiseptics that are used extensively in medical and healthcare facilities for the disinfection of mucous membranes and wounds, and for the sterilization of medical instruments and equipment surfaces that are often contaminated with organic materials. The influence of such materials on the practical use of disinfectants should not be ignored [11].

In the last few years, following the increased circulation of pathogens that are not susceptible to several disinfectants, many biocides and numerous in vitro tests have been developed to assess the effectiveness of these products in specific clinical applications [12]. NTI 30 C4281 BATT1 and NTI 30 C4282 BATT2 (Natural Technologies Italia srl), referred to here as BATT1 and BATT2, are two new natural biocides/detergents formulated with seaweed and plant extracts and synergistic blends of surfactants derived from kelp and other plants of low biological toxicity. Alkyl-amino carboxylate is the active principle in both products.

The aim of the present study was to assess the efficacy of these biocides/detergents against multidrug-resistant nosocomial bacteria.

\section{Materials and methods Disinfectants}

Solutions of BATT1 and BATT2 disinfectants were prepared by dilution in sterile water at 10, 15, 20 and 25\%. The bactericidal effects of BATT1 and BATT2 on multidrug-resistant nosocomial pathogens were assessed using a suspension-inhibition test as recommended by the European Committee for Standardization (CEN) with or without bovine serum albumin (BSA) $0.3 \mathrm{~g} / 100 \mathrm{ml}$ [13]. The bactericidal effects of disinfectants were assessed using a slightly modified suspension-inhibition test as recommended by the CEN. The bactericidal effects of BATT1 and BATT2 on reference strains were tested from manufacturer (data not showed).

\section{Culture methods}

Environmental strains (Acinetobacter baumannii, Pseudomonas aeruginosa, methicillin-resistant Staphylococcus epidermidis, methicillin-resistant Staphylococcus aureus, high-level aminoglycoside-resistant Enterococcus faecalis, extended-spectrum beta-lactamase (ES $\beta \mathrm{L}$ )-producing Klebsiella pneumoniae, Candida albicans, Aspergillus fumigatus and Legionella pneumophila ser.1) were isolated from 2002 to 2005 in the intensive care units (ICUs) of the University Hospital "Federico II" in Naples, Italy, during sanitation checks following nosocomial outbreaks. These microorganisms are recognized as the major hospitalacquired pathogens that cause severe infections such as pneumonia, septicaemia, urinary tract infections and surgical site infections. Throughout this study, the isolates per species were of the same clonal type, showing identical macrorestriction PFGE pattern (data not showed).

Swabs moistened with Brain-Heart Infusion broth were used to sample horizontal surfaces and points of frequent hand contact, as well as monitoring equipment, drug trolleys, respirators and sinks. Contact plates (Rodac; International PBI) with selective agar were used to sample other surfaces (floor, walls and beds), and air was sampled through the Surface Air System (International PBI). Culture specimens were enriched overnight at $37^{\circ} \mathrm{C}$ in BrainHeart Infusion broth and then subcultivated on agar plates.

Isolates were identified by a commercial microidentification system (API 20E; bioMèrieux, Marcy-L'Etoile, France).

Environmental Legionella isolates were obtained from multiple sites in patients' rooms. For each outlet, $2 \mathrm{l}$ of hot water was collected in a sterile bottle that contained $1 \mathrm{ml}$ of a $10 \mathrm{mg} / \mathrm{ml}$ solution of sodium thiosulphate. The water temperature and residual free chlorine were determined immediately after collection. Samples were concentrated by filtration through cellulose acetate membrane filters $(0.22 \mu \mathrm{m}$ pore size) and resuspended into $10 \mathrm{ml}$ of the filtrate. Aliquots of the suspension were plated on to Buffered Charcoal Yeast Extract (BCYE) agar with Legionella Glycine, Vancomycin, Polymyxin B, Cycloheximide, and Wadowsky and Yee selective supplements (Oxoid, Basingstoke, UK). Plates were incubated in $2.5 \% \mathrm{CO}_{2}$ for 5 days at $37^{\circ} \mathrm{C}$ and examined daily for evidence of growth. Gram-negative typical colonies that required L-cysteine for growth were harvested, centrifuged at $3000 \mathrm{rpm}$ for 20 min and resuspended in sterile distilled water prior to serological identification.

Resistance patterns of these microorganisms have been determined as following.

\section{Susceptibility testing and screening}

Susceptibility tests of $K$. pneumoniae, A. baumannii and $P$. aeruginosa were performed using the BD Phoenix (Phoenix Technologies Ltd, San Jose, CA, USA) system (MIC/ 
Table I: Antimicrobial susceptibility patterns of strains tested (*Etest analysis).

\begin{tabular}{|c|c|c|c|c|c|c|c|}
\hline ANTIBIOTIC & K. pneumoniae & A.baumannii & P. aeruginosa & E. faecalis & C. albicans & A. fumigatus & L. pneumophila \\
\hline Amikacin & $<4$ & $>32$ & $>32$ & & & & \\
\hline Amoxicillin-clavulanate & $>16 / 8$ & $>16$ & $>32$ & & & & \\
\hline Ampicillin & $>16$ & & $>32$ & & & & \\
\hline Ampicillin-sulbactam & $>16 / 8$ & & & & & & \\
\hline Aztreonam & $>16$ & & & & & & \\
\hline Cefazolin & $>16$ & & $>64$ & & & & \\
\hline Cefepime & & & 2 & & & & \\
\hline Cefotaxime & $>16$ & $>32$ & $>64$ & & & & \\
\hline Ceftazidime & $>32$ & $>16$ & $>16$ & & & & \\
\hline Ceftriaxone & $>32$ & & & & & & \\
\hline Chloramphenicol & 16 & $>16$ & & & & & \\
\hline Ciprofloxacin & $>2$ & $>2$ & & & & & $>2$ \\
\hline Doxycycline & & & & & & & $>8$ \\
\hline Erythromycin & & & & & & & I \\
\hline Gentamicin & $\leq 2$ & $>8$ & $>8$ & & & & \\
\hline Gentamicin high-level & & & & $>2000$ & & & \\
\hline Imipenem & $\leq 1$ & $>8$ & $>8$ & & & & \\
\hline Levofloxacin & $\leq \mathrm{I}$ & $>2$ & $>2$ & & & & $>2$ \\
\hline Meropenem & $\leq \mathrm{I}$ & $>8$ & $>8$ & & & & \\
\hline Netilmicyn high-level & & & & $>2000$ & & & \\
\hline Nitrofurantoine & $\leq 16$ & & $>512$ & & & & \\
\hline Norfloxacine & $\leq 2$ & & & & & & \\
\hline Piperacillin & $>64$ & $>64$ & 16 & & & & \\
\hline Piperacillin-tazobactam & $\geq 64 / 4$ & $\geq 64 / 4$ & 16 & & & & \\
\hline Streptomycin high-level & & & & $>2000$ & & & \\
\hline Tetracycline & $>8$ & $>8$ & & & & & \\
\hline Trimethoprim-sulfamethoxazole & $\leq 0.5 / 9.5$ & $>2 / 38$ & & & & & \\
\hline
\end{tabular}


Table I: Antimicrobial susceptibility patterns of strains tested (*Etest analysis). (Continued)

\begin{tabular}{ccc}
\hline 5-Fluorocytosine & $>32^{*}$ & $>64^{*}$ \\
\hline Fluconazole & $>1^{*}$ & $>1^{*}$ \\
\hline Itraconazole & $>1 *$ & $>2^{*}$ \\
\hline Amphotericin B & \\
\hline
\end{tabular}

panel susceptibility card) according to the manufacturer's instructions (E. coli 25922 ATCC QC, P. aeruginosa ATCC QC 27853, E. coli ATCC QC 35218)

ES $\beta$ L activity in K. pneumoniae was evaluated using the double-disc synergy test between cephalosporins or monobactam and clavulanate disks on Muller Hinton agar plates. ES $\beta$ L activity was confirmed by Etest cefotaxime/cefotaxime+clavulanic and ceftazidime/ceftazidime + clavulanic acid strip as recommended by the manufacturer (K. pneumoniae ATCC QC 700603).

High-level aminoglycoside resistance in E. faecalis was determined in 96-well microtitre plates using Gentamicin and streptomycin. For QC of HLAR screen tests was used E. faecalis ATCC 29212.

Methicillin and vancomycin were used to test for resistance in Staphylococcus spp. by antibiotic disc diffusion method (S. aureus MRSA ATCC QC 43300).

Susceptibility testing of yeast and mould was detected by E-test using C. albicans ATCC QC 90028 and A. fumigatus ATCC 204305.

Finally, MICs for L. pneumophila were determined using broth microdilution in liquid BCYE medium with selective supplement (L. pneumophila ser.1 ATCC QC 33152).

Throughout this study, results were interpreted according to the Clinical and Laboratory Standards Institute (CLSI) criteria for broth microdilution and disk diffusion methods [14].

Antimicrobial susceptibility testing showed common multidrug-resistant antibiotypes for all the isolated micro-

Table 2: MIC values of $K$. pneumoniae strain identified as ES $\beta$ Lproducer (Etest analysis).

\begin{tabular}{ccccc}
\hline & \multicolumn{4}{c}{ MIC of drug (mg/L) } \\
\hline K. pneumoniae & CTX & CTX+CLA & CAZ & CAZ+CLA \\
\hline MIC & $>16$ & 0.023 & $>32$ & 0.125 \\
\hline
\end{tabular}

CAZ: ceftazidime; CLA: clavulanic acid; CTX: cefotaxime organisms (Table 1). In particular, the antimicrobial susceptibility patterns of the ES $\beta$ L-producing K. pneumoniae showed resistance to penicillins, monobactams and thirdgeneration cephalosporins. Also the K. pneumoniae strain was identified as ES $\beta$ L-producer by Etest analysis (Table 2 ). The antimicrobial susceptibility analysis showed highlevel aminoglycoside-resistance in E. faecalis and methicillin-resistance in Staphylococcus spp. that were either coagulase positive or negative (data not showed).

\section{In vitro quantitative suspension tests}

Microbial suspensions in Luria-Bertani broth were prepared from fresh cultures of the above microorganisms, and subcultivated in non-selective media (Brain-Heart Infusion agar for Gram-negative bacteria, Enterococcus and Candida spp., Tryptone Soy Agar for Staphylococcus spp., Columbia Blood Agar for Aspergillus fumigatus). L. pneumophila was cultivated on a selective medium, BCYE Agar with selective supplements.

Final concentrations of inocula of $10^{8} \mathrm{CFU} / \mathrm{ml}$ bacteria and $10^{6} \mathrm{CFU} / \mathrm{mL}$ yeasts and moulds were measured using a spectrophotometer (UV/VIS Lambda 2, PerkinElmer, Monza, Italy) $\left(\mathrm{OD}_{660} 0.08\right)$. A $100-\mu \mathrm{l}$ suspension for each test was added to tubes that contained $900 \mu \mathrm{l}$ of sterile physiological solution (control) or $900 \mu \mathrm{l}$ of each disinfectant solution at different concentrations $(10,15,20$ and $25 \%$ ), and left for 5,10 and $15 \mathrm{~min}$ at $20 \pm 2{ }^{\circ} \mathrm{C}$ in a thermostatic bath. Each inoculum was prepared twice, with and without BSA $0.3 \mathrm{~g} / 100 \mathrm{ml}$.

After incubation, $100 \mu \mathrm{l}$ were removed from each inoculum and smeared on Bacto D/E Neutralizing agar (Becton Dickinson) after serial dilution $(1: 10,1: 100,1: 1000,1: 10000)$ in phosphate buffered saline (PBS ph 7.4), in order to count the number of colonies surviving on each plate at different dilution. According to the standards, an efficacious biocide must reduce the initial count by 4 or 5 log units, and the efficacy is estimated by the ratio between the number of microorganisms in the starting solution (inocula of $10^{8} \mathrm{CFU} / \mathrm{ml}$ bacteria and $10^{6} \mathrm{CFU} / \mathrm{mL}$ yeasts and moulds) and number of colonies surviving on neutralization plates. Plates were incubated at $37^{\circ} \mathrm{C}$ for $24 \mathrm{~h}$ for bacterial strains and at $32^{\circ} \mathrm{C}$ for $72 \mathrm{~h}$ for C. albicans and A. fumigatus strains. Only the aliquots of the reaction mixture $(100 \mu \mathrm{l})$ that con- 
Table 3: Experimental conditions and microbicidal effect of BATTI e BATT2 on examined microorganisms

\begin{tabular}{|c|c|c|c|c|c|c|c|c|}
\hline Microorganism & $\begin{array}{l}\text { BATTI-BATT2 } \\
\text { concentration }\end{array}$ & $\begin{array}{c}\text { Contact } \\
\text { time } \\
(\mathrm{min})\end{array}$ & $\begin{array}{c}\text { Temp } \\
\left(\mathbf{C}^{\circ}\right)\end{array}$ & $\begin{array}{l}\text { Organic load } \\
\text { (BSA g/l00 ml) }\end{array}$ & $\begin{array}{c}\text { Test } \\
\text { methodology }\end{array}$ & $\begin{array}{c}\text { Inoculum } \\
\left(\log _{10}\right)\end{array}$ & $\begin{array}{c}\text { Biocidal } \\
\text { activity } \\
\text { (log } 10 \text { reduction) } \\
\text { without BSA }\end{array}$ & $\begin{array}{c}\text { Biocidal } \\
\text { activity } \\
\left(\log _{10} \text { reduction }\right) \\
\text { with BSA }\end{array}$ \\
\hline $\begin{array}{l}\text { Acinetobacter } \\
\text { baumannii }\end{array}$ & $25 \%$ & 10 & $20 \pm 2$ & 0.3 & $\begin{array}{l}\text { Suspension } \\
\text { Carrier }\end{array}$ & $10^{8} \mathrm{CFU} / \mathrm{ml}$ & 8 & 8 \\
\hline $\begin{array}{c}\text { Pseudomonas } \\
\text { aeruginosa }\end{array}$ & $\begin{array}{c}\text { undiluted } \\
\text { disinfectants }\end{array}$ & 10 & $20 \pm 2$ & 0.3 & $\begin{array}{l}\text { Suspension } \\
\text { Carrier }\end{array}$ & $10^{8} \mathrm{CFU} / \mathrm{ml}$ & 8 & 8 \\
\hline $\begin{array}{c}\text { MR Staphylococcus } \\
\text { epidermidis }\end{array}$ & $25 \%$ & 10 & $20 \pm 2$ & 0.3 & $\begin{array}{l}\text { Suspension } \\
\text { Carrier }\end{array}$ & $10^{8} \mathrm{CFU} / \mathrm{ml}$ & 8 & 8 \\
\hline $\begin{array}{c}\text { MR Staphylococcus } \\
\text { aureus }\end{array}$ & $25 \%$ & 10 & $20 \pm 2$ & 0.3 & $\begin{array}{l}\text { Suspension } \\
\text { Carrier }\end{array}$ & $10^{8} \mathrm{CFU} / \mathrm{ml}$ & 8 & 8 \\
\hline $\begin{array}{c}\text { ES } \beta \text { L-producing } \\
\text { Klebsiella pneumoniae }\end{array}$ & $25 \%$ & 10 & $20 \pm 2$ & 0.3 & $\begin{array}{l}\text { Suspension } \\
\text { Carrier }\end{array}$ & $10^{8} \mathrm{CFU} / \mathrm{ml}$ & 8 & 8 \\
\hline Candida albicans & $25 \%$ & 10 & $20 \pm 2$ & 0.3 & $\begin{array}{l}\text { Suspension } \\
\text { Carrier }\end{array}$ & $10^{6} \mathrm{CFU} / \mathrm{mL}$ & 6 & 6 \\
\hline Aspergillus fumigatus & $25 \%$ & 10 & $20 \pm 2$ & 0.3 & $\begin{array}{l}\text { Suspension } \\
\text { Carrier }\end{array}$ & $10^{6} \mathrm{CFU} / \mathrm{mL}$ & 6 & 6 \\
\hline $\begin{array}{l}\text { HLAR Enterococcus } \\
\text { faecalis }\end{array}$ & $25 \%$ & 10 & $20 \pm 2$ & 0.3 & $\begin{array}{l}\text { Suspension } \\
\text { Carrier }\end{array}$ & $10^{8} \mathrm{CFU} / \mathrm{ml}$ & 8 & 8 \\
\hline $\begin{array}{l}\text { Legionella pneumophila } \\
\text { ser.l }\end{array}$ & $25 \%$ & 10 & $20 \pm 2$ & 0.3 & $\begin{array}{l}\text { Suspension } \\
\text { Carrier }\end{array}$ & $10^{8} \mathrm{CFU} / \mathrm{ml}$ & 8 & 8 \\
\hline
\end{tabular}

tained L. pneumophila cells and disinfectants after incubation were added to $900 \mu \mathrm{l}$ of neutraliser solution and left at $20 \pm 2{ }^{\circ} \mathrm{C}$ for $3 \mathrm{~min}$. After serial dilution as above, the aliquots were smeared on BCYE agar with supplements. These plates were incubated at $37^{\circ} \mathrm{C}$ in $2.5 \% \mathrm{CO}_{2}$ for 5 days. The test was also carried out on glass surfaces initially contaminated with the microbial inocula, prepared as above, for which the same concentrations were used as for the suspension test, with and without BSA. After 5, 10 and 15 min of sanitation with both disinfectant solutions at different concentration (10, 15, 20 and 25\%), the surfaces were rinsed with a sterile physiological solution, and $100 \mu \mathrm{l}$ was removed from the rinsing solution and smeared on D/E Neutralizing agar after serial dilution. Plates were incubated under the same conditions as above. For L. pneumophila, it was only necessary to use the neutraliser solution and selective medium. The experiments were repeated three times on different days.

\section{Results}

\section{In vitro quantitative suspension tests}

Bacterial, mould and yeast concentration was evaluated by colony counts on agar plates (Bacto D/E Neutralizing agar, BCYE agar with supplements) after incubation under the described conditions.
The results of the in vitro tests were interpreted in accordance with the CEN Standards [13]. According to the standards, an efficacious biocide must reduce the initial count by 4 or 5 log units, and the efficacy is estimated by the ratio between the number of microorganisms in the starting solution (inocula of $10^{8} \mathrm{CFU} / \mathrm{ml}$ bacteria and $10^{6} \mathrm{CFU} / \mathrm{mL}$ yeasts and moulds) and number of colonies surviving on neutralization plates.

Bactericidal activity of BATT1 and BATT2 was observed at a concentration of $25 \%$ after 10 min contact. In vitro tests with BATT1 and BATT2 demonstrated an overall drop in microbial counts, without BSA (Table 3). The same results were obtained in presence of BSA. To reduce $P$. aeruginosa count, it was necessary to use 50\%, 75\% concentrations and finally both undiluted disinfectants, with and without BSA (data not shown). The same results were obtained in the tests carried out on glass surfaces for all nosocomial strains. Also in this test the biocide effect on $P$. aeruginosa was obtained by using undiluted disinfectants with and without an organic substance.

\section{Discussion}

Biodetergents BATT1 and BATT2 are natural products that act as disinfectants and cleaning agents. In our experience, this formulation from seaweed and plant extracts had beneficial and effective results. In vitro tests showed an 
overall drop in bacterial, mould and yeast counts after 10 min contact, with or without BSA, when the disinfectants were used at a $25 \%$ concentration. These products are not consumed by organic residues, which normally reduce the activity of oxidising disinfectants such as chlorine and ozone. The disinfectant effect of chlorine derivatives and ozone occurs when the oxidation of organic substances has been achieved, which implies the need for higherthan-standard concentrations. However, increasing the oxidising disinfectant concentration is not entirely without risk. Evidence for the development of reduced susceptibility caused by excessive exposure to disinfectants, including quaternary ammonium compounds and bisbiguanides, has been reported $[15,16]$. The use of BATT1 and BATT2 disinfectants, especially if alternate, may be beneficial for reducing disinfectant-non-susceptible microbes.

In the last few years, we have observed outbreaks of nosocomial infections caused by multidrug-resistant pathogens that have been selected by excessive and often irrational use of antibiotics and large use of disinfectants $[2,5]$. Following increased circulation of pathogens that are non-susceptible to several disinfectants, numerous in vitro tests have been developed to assess the effectiveness of various biocides in specific clinical situations [12]. In the present study, the efficacy of the two natural biocides/ detergents BATT1 and BATT2 was assessed againstmultidrug-resistant strains isolated in the ICUs of University Hospital "Federico II" in Naples during nosocomial outbreaks. BATT1 and BATT2 disinfectants seem to be efficacious and cost-effective and may be useful in the control of microbial contamination in hospital settings.

It has to be stressed, however, that the reported experiments were carried out in vitro and have only a predictive significance. The efficacy demonstrated by these surrogate testing methods still requires validation from clinical practice.

\section{Competing interests}

The authors declare that they have no competing interests.

\section{Authors' contributions}

GL conceived of the study and carried out its design. MB performed the assays and drafted the manuscript. FG and VDO drafted and edited the manuscript. VQ contributed to the assays performance. MN analyzed the results of tests. MT participated in the design and supervision of the study.

All authors have read and approved the final manuscript.

\section{Acknowledgements}

The authors are grateful to Dr. Giacomo De Maio, Natural Technologies Italia, for his collaboration.

\section{References}

I. Rutala WA, Weber DJ: Control: the role of disinfectants and sterilization. J Hosp Infect 1999, 43(Suppl):S43-45.

2. Bagattini M, Crivaro V, Di Popolo A, Gentile F, Scarcella A, Triassi M, Villari P, Zarrilli R: Molecular epidemiology of extended-spectrum $\beta$-lactamase-producing Klebsiella pneumoniae in a neonatal intensive care unit. J Antimicrob Chemother 2006, 57:979-982.

3. Zarrilli R, Casillo R, Di Popolo A, Tripodi MF, Bagattini M, Cuccurullo S, Crivaro V, Ragone E, Mattei A, Galdieri N, Triassi M, Utili R: Molecular epidemiology of a clonal outbreak of multidrugresistant Acinetobacter baumannii in a university hospital in Italy. Clin Microbiol Infect 2007, 13:48I-9.

4. Levy SB: Antibiotic and antiseptic resistance: impact on public health. Pediatr Infect Dis J 2000, 19(SuppI I0):SI20-2.

5. Webster C, Towner KJ, Humphreys H: Survival of Acinetobacter on three clinically related inanimate surfaces. Infect Control Hosp Epidemiol 2000, 21 (4):246.

6. Chuanchuen R, Beinlich K, Hoang TT, Becher A, Karkhoff-Schweizer RR, Schweizer HP: Cross-resistance between triclosan and antibiotics in Pseudomonas aeruginosa is mediated by multidrug efflux pumps: exposure of a susceptible mutant strain to triclosan selects nfxB mutants overexpressing MexCD-OprJ. Antimicrob Agents Chemother 200I, 45:428-32.

7. Heir E, Langsrud S, Sidhu MS, Steinbakk M: Can disinfectants contribute to antibiotic resistance? Tidsskr Nor Laegeforen 200I, I 2 I(27):320|-6.

8. Sidhu MS, Heir E, Leegaard T, Wiger K, Holck A: Frequency of disinfectant resistance genes and genetic linkage with betalactamase transposon Tn552 among clinical staphylococci. Antimicrob Agents Chemother 2002, 46(9):2797-803.

9. Fluit $C$, Schmitz FJ: Resistance integrons and super-integrons. Clin Microbiol Infect 2004, 10:272-288.

10. Piddock LJV: Clinically Relevant Chromosomally Encoded Multidrug Resistance Efflux Pumps in Bacteria. Clin Microbiol Rev 2006, 19:382-402.

II. Rutala WA: APIC guidelines for selection and use of disinfectants. Am J Infect Control 1996, 24:313-42.

12. Sheldon AT: Food and Drug Administration perspective on topical antiseptic drug product development. In Handbook of topical antimicrobials: industrial applications in consumer products and pharmaceuticals Edited by: Paulson DS. New York: Marcel Dekker; 2003:19-48.

13. European Committee for Standardization: Chemical disinfectants and antiseptics. Quantitative suspension test for the evaluation of bactericidal activity of chemical disinfectants and antiseptics used in food, industrial, domestic, and industrial areas. Test method and requirements (phase 2, step I). European standard EN 1276. Brussels 1997.

14. Clinical and Laboratory Standards Institute: Performance standards for Antimicrobial Susceptibility Testing; Sixteenth informational supplement. Wayne, PA 2006.

15. Thomas L, Maillard JY, Lambert RJ, Russell AD: Development of resistance to chlorhexidine diacetate in Pseudomonas aeruginosa and the effect of a "residual" concentration. J Hosp Infect 2000, 46:297-303.

16. Maillard JY: Bacterial resistance to biocides in the healthcare environment: should it be of genuine concern? J Hosp Infect 2007, 65(Suppl 2):60-72. 